\title{
Assessing the Plant Growth Promoting Activity of Phylloplane Associated Plant Bacteria of Rice
}

\author{
V. Renuga Devi, M. Gomathy*, K.G. Sabarinathan, M. Jeyshree and V. Kalaiyarasi
}

Agricultural College and Research Institute, Killikulam, Vallanadu, India

*Corresponding author

\begin{tabular}{|l|} 
Key w o r d s \\
Phyllosphere \\
microorganisms, \\
Foldscope, Indole \\
acetic acid
\end{tabular}

\section{Introduction}

Rice is one of the important primary cereals produced worldwide. Its cultivation has its own impact as the consumers are more and it has global, social and economic importance. The phyllosphere is a term used in microbiology to refer to the total aboveground portions of plants as habitat for microorganisms.

Phyllosphere environment is commonly occupied by diverse microbes such as bacteria, filamentous fungi, yeast, actinomycetes, where bacteria are the most predominant (Lindow and Leveau 2002). The phyllosphere microbes plays an important role in decomposing natural substances as saprophytes, remediating of remnant pesticides and air pollutants, inducing plant health and development as biofertilizer, phytostimulator, and biopesticides against plant pathogens (Muller and Ruppel 2014). A variety of bacteria, yeasts and filamentous fungi have been isolated from the phyllosphere of several plant species. 
Microbes residing in the phyllosphere can have various life styles and modes of interaction with the host, being neutral residents, latent pathogens, or plant-health and growth promoters (Kai Wang et al., 2016). The bacteria inhabiting the phylloplane are exposed to adverse environmental conditions and can be a good source of diverse bacterial isolates having plant growth promotion potential (Kishore et al., 2005).

\section{Materials and Methods}

\section{Collection of samples}

The rice leaf samples were collected at different stages from the field in and around Killikulam and vallanadu regions.

\section{Isolation and purification of bacterial isolates}

Leaf samples were collected and surface sterilized using $70 \%$ ethanol and washed three times with sterile water. To isolate bacterial population on the adaxial and abaxial leaf surface, both the sides of leaf were imprinted on nutrient agar media. Individual leaf of size $5 \mathrm{~cm}$ each was placed on agar media and the imprint was done by gently pressing the leaf sample using a sterile glass rod (Yadav et al., 2010). The plates were incubated for $24 \mathrm{hrs}$ at $30^{\circ} \mathrm{C}$. Based on the morphological characterization individual colonies were selected and purified in the Nutrient agar medium .The pure culture of bacteria were maintained in nutrient agar slants at $4^{\circ} \mathrm{c}$ for further studies.

\section{Morphological and biochemical characterization of the bacterial isolates}

\section{Colony and cell morphology}

\section{Biochemical characterization}

Biochemical characterization test such as indole production, Methyl red test, VogusProskauer test, Citrate utilization test, Amylase test, Catalase test, Cellulase test, Gram staining was performed according to the procedure given by Thayer and Murray (1977).

\section{Indole production test}

Indole production test was done to test whether the organism can oxidize tryphtophan that results in the formation of indole, pyruvic acid and ammonia.

Bacterial isolates were inoculated in tryptophan broth and incubated for two days. After incubation Kovack's reagent was added and the results were recorded.

\section{Methyl red}

Bacterial isolates were inoculated in the broth and incubated for three days. After incubation Methyl red indicator was added and observed the changes in color of methyl red. Results were recorded. This test can detect the ability of the isolates to oxidize glucose with the production of high concentration of acid.

\section{Voges proskauer test}

Bacterial isolates were inoculated in the MRVP broth and incubated for two days. After incubation 12 drops of $\mathrm{VP}$ reagent -1 (Napthol solution) and 2-3 drops of VP reagent- II $(40 \% \mathrm{KOH})$ was added and observed for change in red colour that was recorded to be a positive reaction.

\section{Citrate utilization test}

Bacterial isolates were streaked on simmon's citrate agar and incubated for three days. After incubation the colour change was observed and development of green to blue color in medium indicates positive. The results were noted for comparison. 


\section{Enzyme activity}

\section{Amylase test (Buzzini and Martini, 2002)}

Bacterial isolates were streaked on starch agar medium and incubated for $48 \mathrm{~h}$ at $30 \pm 1^{\circ} \mathrm{C}$. After incubation petriplates were flooded with Lugol's iodine solution for $30 \mathrm{sec}$ and drained.

Formation of yellow zone around the colonies against dark blue background, indicates the positive starch hydrolysis. Results were recorded.

\section{Catalase test (Nutaratat et al., 2014)}

The bacterial isolates were streaked on nutrient agar plates and incubated for $48 \mathrm{~h}$ at $30 \pm 1{ }^{\circ} \mathrm{C}$. After incubation few drops of $3 \%$ hydrogen peroxide $(\mathrm{H} 2 \mathrm{O} 2)$ was added to the grown culture and observed for appearance of effervescence which indicates positive for catalase test. Production of effervescence indicates presence of oxygen.

\section{Cellulase (Buzzini and Martini, 2002)}

The bacterial isolates were streaked on the CMC agar medium and incubated for 2 days. After incubation plates were flooded with $1 \%$ congo red and observed for zone formation around the colony. Results were tabulated.

\section{Estimation of IAA production}

Culture filtrate to a quantity of $8 \mathrm{ml}$ was taken and $2 \mathrm{ml}$ of Salkowski reagent was added and incubated at room temperature in dark for 30 minutes for the development of pink colour.

The optical density was read at $530 \mathrm{~nm}$. The results were read from standard graph and expressed as $\mu \mathrm{g} / \mathrm{L}$. The IAA production was determined using the Salkowski method (Rahman et al., 2010).

\section{Results and Discussion}

At different growth stages of rice leaf samples were collected and the bacterial diversity was analyzed using leaf imprinting technique in nutrient agar medium. Bacterial population was enumerated and based on morphology isolates were grouped and purified. After purification the isolates were characterized (Table 1; Plate 2).

The results revealed that milky stage have more number of bacterial colonies compared to other critical stages. Moreover, this stage has more pigmented bacterial colonies (345 $\mathrm{cfu} / \mathrm{m}^{2}$ ) followed by panicle initiation stage $\left(155 \mathrm{cfu} / \mathrm{m}^{2}\right)$ and least number of bacteria was observed at nursery stage $\left(115 \mathrm{cfu} / \mathrm{m}^{2}\right)$ (Plate 5). The hike in the bacterial population especially in the milky stage might be due to meet out the nutritional and physiological requirements when compared to other stages. Gram negative bacterial population was predominant, together with a few pigmented bacteria was observed by Venkatachalam et al., (2016).

\section{Characterization of bacterial isolates}

The bacterial isolates were further studied for their morphological and biochemical characteristics.

\section{Morphological characterization}

Dorko et al., (2000) reported that Cryptococcus neoformans are white, grey in colour, smooth in texture and had raised colony. The work performed on morphological and physiological characterizations of Saccharomyces cerevisiae strains exhibited rough and smooth colonies (Reis et al., 2013). In this study, all the bacterial isolates were observed for their morphological characters such as colony shape, pigment, form, margin and elevation. 
The color of the colonies were dark brown, yellow, white dull white, orange, dark yellow and were mostly had round margin, irregular form and also most of the isolates were round shaped (Table1: Plate 2).

\section{Gram staining}

Gram staining is a common technique used to differentiate two large groups of bacteria based on the different cell wall constituents. The gram stain procedure distinguishes Gram positive and Gram negative groups. Among the 10 bacterial isolates, 8 isolates identified to be gram positive because the isolates had shown violet colour in staining. The bacterial cells were observed through foldscope, a frugal microscope. (Table:1, Plate1). Similarly Rohomania et al., (2015) performed the gram staining and reported the 12 gram negative and 12 gram positive bacteria isolated from Fresh and Salted Hilsa.

\section{Biochemical characterization and enzyme activity}

In this study all the bacterial isolates showed positive results in various biochemical tests such as citrate utilization, indole production (Table 2) For MR test and VP test only 8 isolates showed the positive results (Table 2).

Both Amylase and catalase activity showed positive but only in cellulase all the isolates showed the negative results (Table 2, Plate 3 ). The results revealed that the bacterial isolates obtained from the phyllosphere of rice have the ability to utilize the citrate and also have the ability to produce indole. Similar results were obtained by Jeyashri et al., (2019) who reported that most of the phyllosphere yeast isolates from rice showed positive results in biochemical characterization and enzyme activity.

Table.1 Colony Morphology and gram staining of the phyllosphere bacterial isolates from rice

\begin{tabular}{|c|c|c|c|c|c|c|}
\hline $\begin{array}{l}\text { Bacterial } \\
\text { isolates }\end{array}$ & $\begin{array}{c}\text { Gram's } \\
\text { stain }\end{array}$ & Shape & Pigment & Form & Margin & Elevation \\
\hline B1 & + ve & Rod & Dark brown & Irregular & Round & Raised \\
\hline B2 & + ve & Rod & Yellow & Irregular & Round & Flat \\
\hline B3 & + ve & Rod & Dark yellow & Irregular & Round & Raised \\
\hline B4 & - ve & Rod & White & Irregular & smooth & Convex \\
\hline B5 & + ve & Rod & Orange & Irregular & $\begin{array}{c}\text { Serrated } \\
\text { edges }\end{array}$ & Flat \\
\hline B6 & + ve & Rod & White & Irregular & Round & Flat \\
\hline B7 & + ve & Rod & White & Irregular & Round & Flat \\
\hline B8 & - ve & Rod & White & Irregular & Round & Convex \\
\hline B9 & + ve & Rod & Dull White & Irregular & Serrated & Raised \\
\hline B10 & + +ve & Rod & Brown & Irregular & Round & Raised \\
\hline
\end{tabular}


Table.2 Biochemical and enzyme activity of phyllosphere bacterial isolates from rice

\begin{tabular}{|c|l|l|l|l|l|l|l|}
\hline $\begin{array}{l}\text { Bacterial } \\
\text { isolates }\end{array}$ & Cellulase & Amalyse & $\begin{array}{c}\text { Citrate } \\
\text { Utilization }\end{array}$ & MR & VP & Catalase & $\begin{array}{c}\text { Indole } \\
\text { Production }\end{array}$ \\
\hline B1 & $-v e$ & $+v e$ & $+v e$ & $+v e$ & $+v e$ & $+v e$ & $+v e$ \\
\hline B2 & $-v e$ & $+v e$ & $+v e$ & $-v e$ & $-v e$ & $+v e$ & $+v e$ \\
\hline B3 & $-v e$ & $+v e$ & $+v e$ & $+v e$ & $+v e$ & $+v e$ & $+v e$ \\
\hline B4 & $-v e$ & $+v e$ & $+v e$ & $+v e$ & $+v e$ & $+v e$ & $+v e$ \\
\hline B5 & $-v e$ & $+v e$ & $+v e$ & $+v e$ & $+v e$ & $+v e$ & $+v e$ \\
\hline B6 & $-v e$ & $+v e$ & $+v e$ & $+v e$ & $-v e$ & $+v e$ & $+v e$ \\
\hline B7 & $-v e$ & $+v e$ & $+v e$ & $+v e$ & $+v e$ & $+v e$ & $+v e$ \\
\hline B8 & $-v e$ & $+v e$ & $+v e$ & $+v e$ & $+v e$ & $+v e$ & $+v e$ \\
\hline B9 & $-v e$ & $+v e$ & $+v e$ & $-v e$ & $-v e$ & $+v e$ & $+v e$ \\
\hline B10 & $-v e$ & $+v e$ & $+v e$ & $+v e$ & $+v e$ & $+v e$ & $+v e$ \\
\hline
\end{tabular}

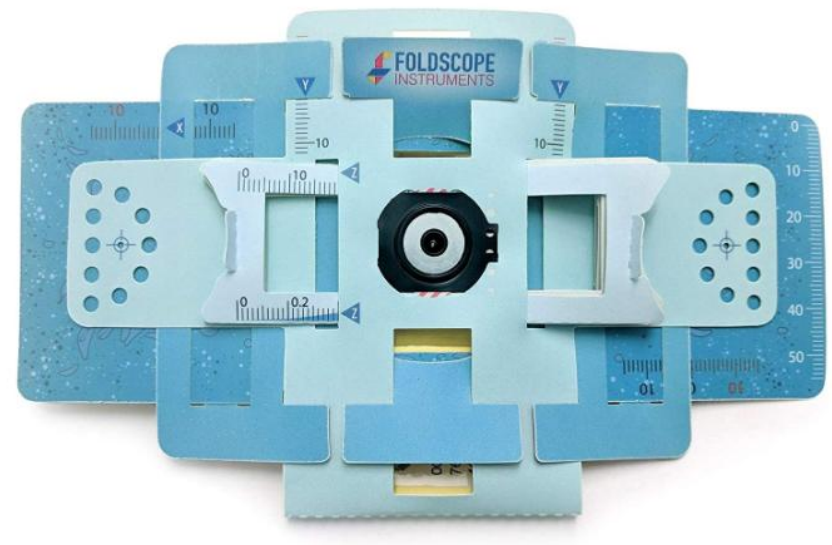

Plate.1 Foldscope - Frugal Microscope


Plate.2 Bacterial isolate and stained cells under foldscope 


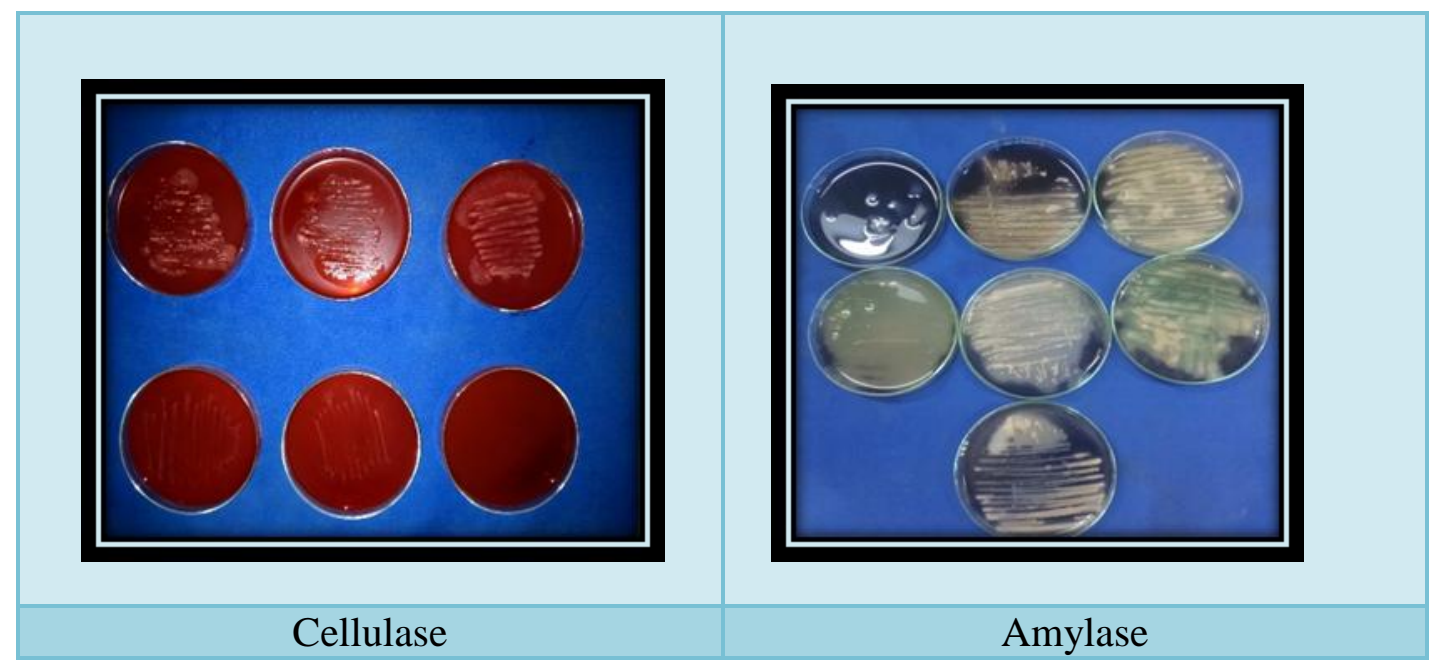

Plate.3 Determination of Enzyme Activity

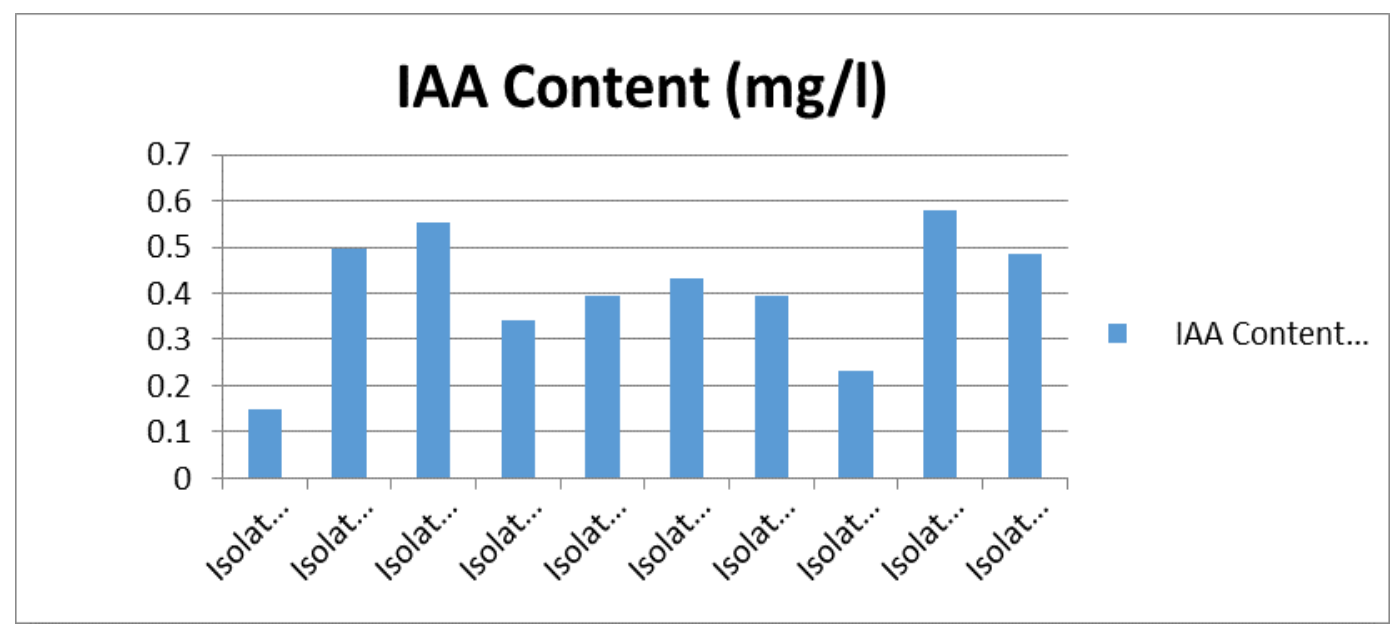

Plate.4 IAA production by phyllosphere bacterial isolates of rice

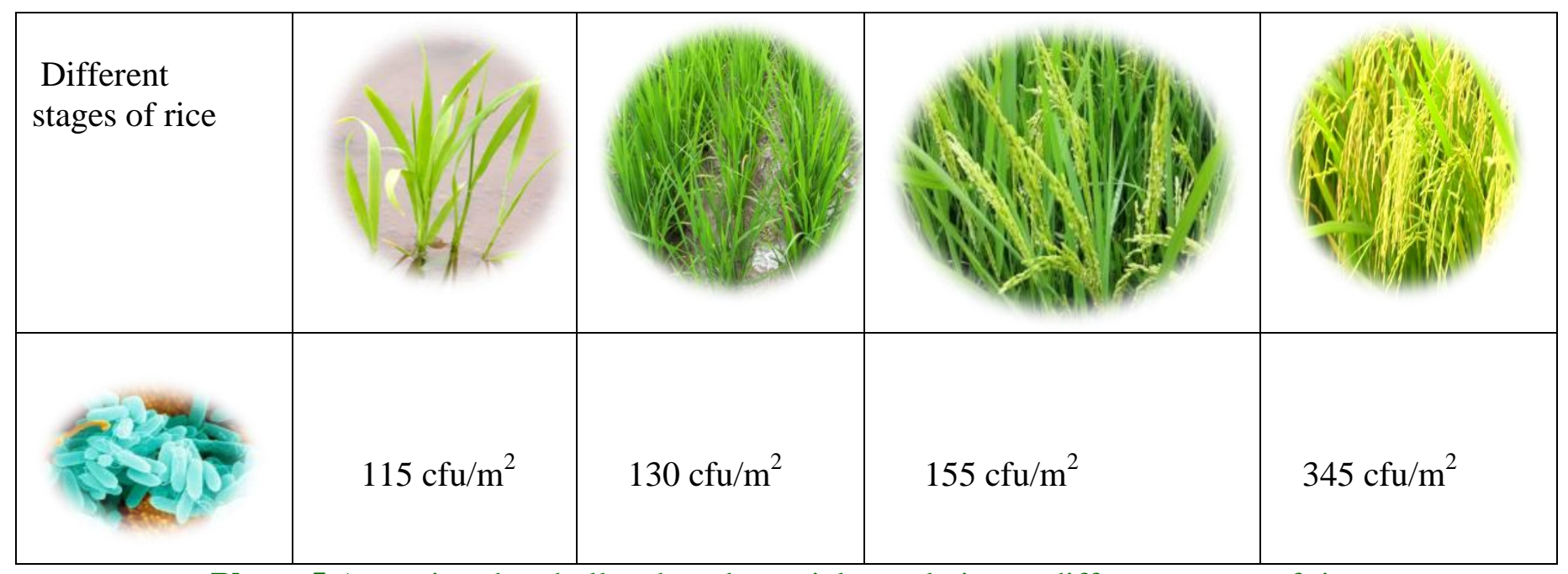

Plates.5 Assessing the phyllosphere bacterial population at different stages of rice 


\section{IAA activity}

IAA activity was analyzed for the bacterial isolates and among the isolates, isolate B9 showed higher production of IAA followed by the isolates B3, B2 and B10 (Plate 4). Similar results were observed by Arun Kumar et al., (2019) who also reported that IAA production was higher in the drought tolerant isolate obtained from phyllosphere of rice. Mohite, 2013 isolated bacteria from rhizosphere soil and evaluated the isolates for the production of IAA and found many of the isolated produced huge quantities of IAA. Jeyashri et al., (2019) reported that Rhodotorula paludigena isolated from the phyllosphere of rice produced higher quantities of IAA $(77.18 \mu \mathrm{g} \mathrm{ml}-1)$ in the presence of $0.1 \%$ tryptophan.

\section{References}

Bodenhausen, N., Bortfeld-Miller, M., Ackermann, M., \& Vorholt, J. A. (2014). A synthetic community approach reveals plant genotypes affecting the phyllosphere microbiota. PLoS genetics, 1O(4), e1004283.

Buzzini, P., \& Martini, A. (2002). Extracellular enzymatic activity profiles in yeast and yeast-like strains isolated from tropical environments. Journal of Applied Microbiology, 93(6), 10201025.

Dorko, E., Kmetova, M., Dorko, F., Bracokova, I., Danko, J., \& Svicky, E. (2000). Prevalence of Cryptococcus neoformans in clinical specimens. Folia microbiologica, 45(4), 369-372.

Jeyashri, M., Gomathy, M., Sabarinathan, K. G., Subhashini, R., \& Suresh, S. (2019). Screening of Phyllosphere Yeast of Rice for the Production Enzymes and Solubilisation of Minerals. Int. J. Curr. Microbiol. App. Sci, 8(8), 465-472.

Kishore, G.K, S. Pande and A. R.
Podile(2005), Phylloplane bacteria increase seedling emergence, growth and yield of field - grown groundnut. (Arachis hypogaea L). Lett.Appl.Microbiol.,40, 260-268.

Kumar, D. A., Sabarinathan, K. G., Kannan, R., Balachandar, D., \& Gomathy, M. (2019). Isolation and Characterization of Drought Tolerant Bacteria from Rice Phyllosphere. Int. J. Curr. Microbiol. App. Sci, 8(6), 2655-2664.

Mohite, B. (2013). Isolation and characterization of indole acetic acid (IAA) producing bacteria from rhizospheric soil and its effect on plant growth. Journal of soil science and plant nutrition, 13(3), 638-649.

Muller . T and Ruppel S (2014). Progress in cultivation - independent phyllosphere microbiology. FEMS Microbiol . Ecol .87:2-17.

Nutaratat, P., Srisuk, N., Arunrattiyakorn, P., \& Limtong, S. (2014). Plant growth promoting traits of epiphytic and endophytic yeasts isolated from rice and sugar cane leaves in Thailand. Fungal biology, 118(8), 683-694.

Rahman, A., Sitepu, I. R., Tang, S.-Y., and Hashidoko, Y. (2010). Salkowski's reagent test as a primary screening index for functionalities of rhizobacteria isolated from wild dipterocarp saplings growing naturally on medium-strongly acidic tropical peat soil. Bioscience, biotechnology, and biochemistry, 74(11), 2202-2208.

Rohomania, T., Saha, M. L., Hossain, A., \& Rahman, M. S. (2015). Morphological and Biochemical Characterization of Bacteria Isolated from Fresh and Salted Hilsa, Tenualosa ilisha (Hamilton, 1822). Bangladesh Journal of Microbiology, 7-13.

Regina Ceccato-Antonini. 2013. Characteristics of Saccharomyces cerevisiae yeasts exhibiting rough 
colonies and pseudohyphal morphology with respect to alcoholic fermentation."

Steven E Lindow, Johan H.J Leveau (2002) . Phyllosphere microbiology. current opinion in Biotechnology,13(3) , 238 243.

Thayer, D., and Murray, J. O. (1977). Physiological, biochemical and morphological characteristics of mesquite wood-digesting bacteria. Microbiology, 101(1), 71-77.
Venkatachalam et al., (2016). Diversity and functional traits of culturable microbiome members, including cyanobacteria in the rice phyllosphere. Plant Biology, 18(4), 627-637.

Wang K, Sipilä T. P., \& Overmyer, K. (2016).The isolation and characterization of resident yeasts from the phylloplane of Arabidopsis thaliana. Scientific reports, 6, 39403.

\section{How to cite this article:}

Renuga Devi, V., M. Gomathy, K.G. Sabarinathan, M. Jeyshree and Kalaiyarasi, V. 2020. Assessing the Plant Growth Promoting Activity of Phylloplane Associated Plant Bacteria of Rice. Int.J.Curr.Microbiol.App.Sci. 9(07): 384-391.

doi: https://doi.org/10.20546/ijcmas.2020.907.042 